\title{
Sex-, tissue-, and exposure duration-dependent effects of imidacloprid modulated by piperonyl butoxide and menadione in rats. Part I: oxidative and neurotoxic potentials
}

\author{
Mustafa Yardimci ${ }^{1}$, Yusuf Sevgiler ${ }^{2}$, Eyyup Rencuzogullari², Mehmet Arslan³, Mehmet \\ Buyukleyla ${ }^{4}$, and Mehmet Yilmaz
}

Adiyaman University, Institute of Natural and Applied Sciences, Department of Biologyl, Adiyaman University, Faculty of Science and Letters, Department of Biology, Adiyaman', Ardahan University, Health Sciences College, Department of Nursery, Merkez, Ardahan', Cukurova University, Institute of Natural and Applied Sciences, Department of Biology,

Balcali, Adana ${ }^{4}$, Turkey

Received in July 2014

CrossChecked in July 2014

Accepted in November 2014

\begin{abstract}
Earlier research has evidenced the oxidative and neurotoxic potential of imidacloprid, a neonicotinoid insecticide, in different animal species. The primary aim of this study was to determine how metabolic modulators piperonyl butoxide and menadione affect imidacloprid's adverse action in the liver and kidney of Sprague-Dawley rats of both sexes. The animals were exposed to imidacloprid alone $\left(170 \mathrm{mg} \mathrm{kg}^{-1}\right)$ or in combination with piperonyl butoxide $\left(100 \mathrm{mg} \mathrm{kg}^{-1}\right)$ or menadione $\left(25 \mathrm{mg} \mathrm{kg}^{-1}\right)$ for 12 and $24 \mathrm{~h}$. Their liver and kidney homogenates were analysed spectrophotometrically for glutathione peroxidase, glutathione $S$-transferase, catalase, total cholinesterase specific activities, total glutathione, total protein content, and lipid peroxidation levels. Imidacloprid displayed its prooxidative and neurotoxic effects predominantly in the kidney of male rats after $24 \mathrm{~h}$ of exposure. Our findings suggest that the observed differences in prooxidative and neurotoxic potential of imidacloprid could be related to differences in its metabolism between the sexes. Co-exposure (90-min pre-treatment) with piperonyl butoxide or menadione revealed tissue-specific effect of imidacloprid on total cholinesterase activity. Increased cholinesterase activity in the kidney could be an adaptive response to imidacloprid-induced oxidative stress. In the male rat liver, co-exposure with piperonyl butoxide or menadione exacerbated imidacloprid toxicity. In female rats, imidacloprid+menadione co-exposure caused prooxidative effects, while no such effects were observed with imidacloprid alone or menadione alone. In conclusion, sex-, tissue-, and duration-specific effects of imidacloprid are remarkable points in its toxicity.
\end{abstract}

KEY WORDS: catalase; cholinesterase; glutathione peroxidase; glutathione S-transferase; neonicotinoids; oxidative stress

Neonicotinoids account for approximately one fourth of the world insecticide market (1). It is a novel insecticide group that has been replacing organophosphate, organochlorine, and pyrethroid insecticides (2) and is highly effective against piercing-sucking pests in the crops and in flea control in cats and dogs (3). Imidacloprid (IMI; IUPAC name: $N$ - $\{1$-[(6-chloro-3-pyridyl) methyl]-4,5dihydroimidazol-2-yl $\}$ nitramide; CAS no: 13826141-3) is a systemic neonicotinoid insecticide that has first been registered in 1994 (4). Turkey alone used nearly 500 tonnes of it in 2012 . 
Imidacloprid and other neonicotinoids act on insect nicotinic acetylcholine receptors (nAChRs), and fundamental differences between the nAChRs of insects and mammals make them remarkably "safe" for the latter (5). However, what is not safe for mammals are IMI's metabolites, especially nitroguanidine and aminoguanidine derivatives (6-8). Mammalian CYP450s, (CYP3A4 in particular) and aldehyde oxidase (AOX; EC 1.2.3.1) are two important enzymes in its metabolism (9). CYP450s are responsible for the conversion of IMI to 5-hydroxy, olefin, nitrosoimine, guanidine, and urea derivatives (10), while AOX converts IMI to nitrosoguanidine and aminoguanidine metabolites (11).

Many studies have shown the oxidative and neurotoxic potential of IMI in a variety of animal species, including rats (12-19). However, none has investigated how biotransformation affects prooxidative and neurotoxic effects of IMI in mammals and whether it depends on sex, tissue, or exposure duration. Modulators such as piperonyl butoxide (PBO) and menadione (MEN) are very useful to understand how biotransformation affects the toxicity of a chemical under investigation $(20,21)$. PBO (IUPAC name: 5-[2-(2-butoxyethoxy) ethoxymethyl]-6-propyl-1,3-benzodioxole; CAS no: 51-03-6) is a methylenedioxyphenyl compound used to enhance the potency of certain pesticides by inhibiting CYP450s and esterases (22-24). As Tomizawa and Casida (5) stated in their review that PBO synergized with IMI in toxicity to insects, we wondered what would be the toxicity (oxidative stress and cholinesterase activity) of this combination in mammals.

Menadione (IUPAC name: 2-Methylnaphthalene1,4-dione; CAS no: 58-27-5) is a specific inhibitor of $\mathrm{AOX}$ and it can increase reactive oxygen species (ROS) levels as a redox active compound (25-27). However, according to Kerver et al. (28), it also lowers superoxide radical formation by inhibiting AOXcatalysed 3,39-diaminobenzidine (DAB) oxidation in the liver and intestine of male Wistar rats and, according to Al-Omar and Al-Arifi (29), superoxide radical and hydrogen peroxide formation by inhibiting AOX-mediated oxidation in Dunkin-Hartley guinea pig liver. This is why we decided to also investigate the effects of MEN on IMI-induced oxidative stress.

By determining how these two metabolic modulators affect the oxidative and neurotoxic potential of IMI in rats, we hoped to get an insight into the mechanisms behind IMI toxicity and their relation to sex, tissue, and exposure duration.

\section{MATERIALS AND METHODS}

\section{Chemicals}

Pure IMI and MEN crystals were purchased from Supelco and Sigma, respectively (Sigma-Aldrich Chemie $\mathrm{GmbH}$ ). Technical grade (90\%) PBO was supplied from Aldrich (Sigma-Aldrich Chemie $\mathrm{GmbH})$. All other chemicals used were of analytical grade.

\section{Animals and treatment}

This study was approved by the ethics committee of the Cukurova University Medical Sciences, Experimental Research, and Application Centre (no:11, date: 2 July 2010), which also supplied young adult, male and female rats (weighing about $200 \mathrm{~g}$, regardless of sex) of the Sprague-Dawley strain (Rattus norvegicus var. albinos). They were separated by sex, kept in clean plastic cages, and acclimatised to laboratory conditions for seven days. Wood shavings in cages were changed every day. Laboratory temperature was $22 \pm 1^{\circ} \mathrm{C}$ and relative humidity was $65 \pm 5 \%$. The rats were maintained under natural photoperiod and fed ad libitum.

Feeding ceased $24 \mathrm{~h}$ before toxicity experiments. The rats were randomly divided in six groups of six animals. One group received physiological saline (saline control) to determine the basal levels of the parameters tested. All the chemicals used in this study were dissolved in dimethylsulfoxide (DMSO) and were given intraperitoneally (i.p.). As DMSO has some biphasic effects, which can be antioxidant or prooxidant (30), we also included a solvent control, the DMSO group. Data obtained from treated groups, however, were compared with this group only instead of saline control to display the toxicity of the investigated chemicals against the solvent's effects. This is why we refer to the DMSO control as control.

One group received only IMI (IMI group) in the $\mathrm{LC}_{50}$ dose of $170 \mathrm{mg} \mathrm{kg}^{-1}$ (31). One group received $100 \mathrm{mg} \mathrm{kg}^{-1}$ of PBO only (PBO group). One received $25 \mathrm{mg} \mathrm{kg}^{-1}$ of MEN only (MEN group). Two groups received pre-treatment with either $\mathrm{PBO}$ or MEN $90 \mathrm{~min}$ before receiving IMI in the same doses as 
described above (IMI+PBO group and IMI+MEN group, respectively).

None of the rats died during the experiment. The rats were killed by cervical dislocation after $12 \mathrm{~h}$ or $24 \mathrm{~h}$ of exposure. Liver and kidney tissues were dissected on an ice plate, washed in physiological saline to remove blood residues, blotted dry, weighed, and stored at $-80^{\circ} \mathrm{C}$ until biochemical analysis.

\section{Biochemical analyses}

All biochemical analyses were done using a Shimadzu UV1800 UV-Visible spectrophotometer (Shimadzu, Kyoto, Japan). Liver and kidney tissues were homogenised using a glass-teflon homogeniser (WiseStir HS30E, Daihan Scientific, Seoul, Korea) in an ice-containing bucket with $50 \mathrm{mmol} \mathrm{L}^{-1} \mathrm{pH} 7.4$ phosphate buffer that contained $1.17 \% \mathrm{KCl}$ and centrifuged at $10500 \mathrm{xg}$ at $4{ }^{\circ} \mathrm{C}$ for $30 \mathrm{~min}$ (Universal 320R, Hettich, Tuttlingen, Germany). The obtained supernatants from each homogenate were used to analyse glutathione peroxidase (GPx), glutathione $S$-transferase (GST), catalase (CAT), total cholinesterase ( $\mathrm{tChE})$, total glutathione ( $\mathrm{tGSH})$, thiobarbituric acid reactive substances (TBARS), and total protein content. Aliquots of liver or kidney homogenates were mixed with $10 \% 5$-sulphosalicylic acid $(1: 0.5 \mathrm{v} / \mathrm{v})$, then centrifuged at $10,500 \mathrm{~g}$ at $4{ }^{\circ} \mathrm{C}$ for $5 \mathrm{~min}$, and the obtained supernatants used to measure tGSH content based on the recycling reaction with 5,5'-dithiobis-(2-nitrobenzoic acid) (DTNB) in the presence of glutathione reductase (GR) (32). The incubation medium contained $0.3 \mathrm{mmol} \mathrm{L}^{-1}$ of NADPH in stock buffer $\left(143 \mathrm{mmol} \mathrm{L}^{-1}\right.$ of sodium phosphate $/ 6.3 \mathrm{mmol} \mathrm{L}^{-1}$ of Na-EDTA, adjusted to $\mathrm{pH}$ 7.5), $6 \mathrm{mmol} \mathrm{L}^{-1}$ of DTNB, $50 \mathrm{U} / \mathrm{mL}$ of GR, and $25 \mu \mathrm{L}$ of sample. 5-thio-2-nitrobenzoic acid formation was monitored continuously at $412 \mathrm{~nm}$ for $3 \mathrm{~min}$. The tGSH content was determined by comparison with a standard curve generated using GSH and expressed as $\mu \mathrm{mol} \mathrm{L}-1$ per mg of protein.

Glutathione peroxidase activity was assayed at $37^{\circ} \mathrm{C}$ and $340 \mathrm{~nm}$ using GSH and $t$-butylhydroperoxide as substrates (33). The reaction medium contained $100 \mathrm{mmol} \mathrm{L}^{-1}$ of GSH, $10 \mathrm{U} \mathrm{mL}^{-1}$ of GR, $2 \mathrm{mmol} \mathrm{L}^{-1}$ of NADPH, and $7 \mathrm{mmol} \mathrm{L}^{-1}$ of $t$-butylhydroperoxide. Specific activity was expressed as $\mathrm{U} / \mathrm{mg}$ protein using the molar extinction coefficient of $6.22 \mathrm{mmol} \mathrm{L}^{-1} \mathrm{~cm}^{-1}$.

Catalase activity was determined according to Beutler (33) as a decrease in absorbance of 10 mmol L-1 $\mathrm{H}_{2} \mathrm{O}_{2}$ at $37^{\circ} \mathrm{C}$ for $2.5 \mathrm{~min}$. The reaction was initiated by adding the supernatant. The degradation rate of $\mathrm{H}_{2} \mathrm{O}_{2}$ by $\mathrm{CAT}$ was measured at $230 \mathrm{~nm}$. Specific activity was expressed as $\mathrm{U} / \mathrm{mg}$ protein using the molar extinction coefficient of $0.071 \mathrm{mmol} \mathrm{L}^{-1} \mathrm{~cm}^{-1}$.

Glutathione $S$-transferase activity was measured according to Habig et al. (34), using 1-chloro-2,4dinitrobenzene (CDNB) as substrate. Enzyme activity was determined by monitoring changes in absorbance at $340 \mathrm{~nm}$, which reflects the rate of $\mathrm{CDNB}\left(1 \mathrm{mmol} \mathrm{L}^{-1}\right)$ conjugation with GSH $\left(1 \mathrm{mmol} \mathrm{L}^{-1}\right)$ at $30{ }^{\circ} \mathrm{C}$ for 2 minutes. Specific activity was expressed as $\mathrm{U} / \mathrm{mg}$ protein using the molar extinction coefficient of $9.6 \mathrm{mmol} \mathrm{L}^{-1} \mathrm{~cm}^{-1}$.

For TBARS measurement, supernatants were mixed with $10 \%$ trichloroacetic acid, vortexed, and then centrifuged at $11 \mathrm{~g}$ for $10 \mathrm{~min}$. After the addition of thiobarbituric acid, samples were vortexed and held in a water bath at $100{ }^{\circ} \mathrm{C}$ for $10 \mathrm{~min}$. Absorbance of the samples was measured at $535 \mathrm{~nm}$, and these values were converted to TBARS concentration using the standard graphic prepared with 1,1',3,3'tetramethoxypropane (35). TBARS concentration was expressed in nmoles per $\mathrm{mg}$ of protein.

Total protein content was measured using the Folin-phenol reagent according to Lowry et al. (36). The absorbance was measured at $750 \mathrm{~nm}$ and converted to concentration using bovine serum albumin as the standard. The concentration was expressed in $\mathrm{mg}$ in per $\mathrm{mL}$ of supernatant.

Since no inhibitor was used to differentiate cholinesterase types, we determined the total $\mathrm{ChE}$ activity in the supernatants. Briefly, supernatants were incubated with $10 \mathrm{mmol} \mathrm{L}^{-1}$ DTNB in $\mathrm{pH} 8$ phosphate buffer for $5 \mathrm{~min}$. Activity was started by adding $15 \mathrm{mmol} \mathrm{L}^{-1}$ acetylthiocholine iodide as substrate and monitored for $5 \mathrm{~min}$ at $412 \mathrm{~nm}$ (37). Specific activity was expressed as nmol L-1 of thiocholine formed per min per mg of protein using the molar extinction coefficient of $13.6 \mathrm{mmol} \mathrm{L}^{-1} \mathrm{~cm}^{-1}$.

\section{Statistical analyses}

The results are expressed as mean \pm standard error of mean (SEM) of six samples. The groups were compared using the Mann-Whitney $U$-test and the Kruskal-Wallis rank test of variance. The data were analysed using the Statistical Package for Social Sciences (SPSS, SPSS Inc., Chicago, IL, USA) version 17. The level of significance was set at $P<0.05$. We did not perform the statistical analysis considering exposure durations in the same tissue because of the significant differences between control values. 
Therefore, the results for different exposure durations for the same tissue are given in separate tables.

\section{RESULTS AND DISCUSSION}

Oxidative stress is a part of IMI toxicity that has been evidenced by earlier studies (16-19). Our study has added to this knowledge by showing that IMI toxicity varies with sex, tissue, and exposure duration.

Sex-and duration-specific effects of IMI in rat liver and kidney

In the first $12 \mathrm{~h}$ of exposure, we found no effect on oxidative stress parameters and $\mathrm{tChE}$ regardless of sex and tissue (Tables 1 and 2), except for a decrease in liver tGSH in male rats (Table 2). The highest oxidative toxicity and neurotoxicity was observed in the kidney of male rats after $24 \mathrm{~h}$ of exposure: $\mathrm{tGSH}$, TBARS, and tChE increased, but protein content decreased (Table 3 ). The only effect found in female rats was increase in kidney GST activity after $24 \mathrm{~h}$ of exposure (Table 3 ). Kidney is the target organ for most xenobiotics, as proximal tubular cells are able to accumulate slightly acidic and basic compounds, amino acid conjugates, and quaternary compounds at toxic levels (38). The duration-dependent effect of IMI in our study is most probably related to its metabolism. Broznić et al. (39) reported that IMI was mostly cleared from the liver of BALB/C mice within $24 \mathrm{~h}$ and from the kidney within $48 \mathrm{~h}$. In rats, kidney clearance is generally completed within $24 \mathrm{~h}$ after oral or intravenous administration (40).

Oxidative effects of IMI were more pronounced in both tissues of the male rats regardless of exposure duration. It is likely that different metabolic rates resulted in sex-related toxicity differences in the IMIexposed rats. Induced CYP450 activities by nicotine enantiomers lead to oxidative stress conditions in Chinese hamster ovary K1 cell line (41). Kyerematen et al. (42) reported faster metabolism of nicotine in the kidney and liver of male than female SpragueDawley rats. Being a nicotine-like compound, IMI is metabolised more effectively in males than in females (40), and its faster metabolism could result in higher ROS production.

Imidacloprid is metabolised mainly by CYP3A4, and by CYP2C19, CYP2A6, CYP2C9, CYP2D6, CYP2E1, CYP1A2, and CYP2B6 (10). Kammerer et al. (43) reported that protein kinase inhibitor ML3403 was metabolised in vitro by CYP450 isoenzymes (CYP3A4, CYP2C19, CYP1A2, and CYP2D6) much faster in male than in female Wistar rats. Sundseth and Waxman (44), in turn, found that clofibrate-induced liver and kidney CYP4A expression was higher in Fischer 344 male rats than in female, probably under hormonal influence.

Aldehyde oxidase functions as a ROS source (45) and is affected by sex hormones such as oestradiol, which may account for sex-specific differences in IMI toxicity, even though we did not analyse this enzyme's activity. Huh et al. (46) reported that $\mathrm{Fe}^{2+}$-induced lipid peroxidation was higher in male than in female Sprague-Dawley liver, and that oestradiol, possibly by the way of AOX inhibition, alleviated lipid peroxide formation compared to progesterone and testosterone. Ventura and Dachtler (47) suggested that androgens increase AOX activity in the liver of male and female $\mathrm{C} 57 \mathrm{BL} / 6 \mathrm{~J}$ mice, and that oestradiol decreases it in males.

Our results suggest that increased tChE activity could be related to increased lipid peroxidation and tGSH levels and decreased protein content in the kidney of male rats after $24 \mathrm{~h}$ of exposure (Table 3 ). In a study by Abu-Donia et al. (13), IMI increased AChE activity in newborn Sprague-Dawley rats via maternal exposure, and the authors suggested that this induction occurred due to apoptotic events via cellular $\mathrm{Ca}^{2+}$-uptake. In another study (48), neonicotinoid insecticides acetamiprid and IMI induced cellular $\mathrm{Ca}^{2+}$ uptake via $\alpha_{7}$ nAChRs in Sprague-Dawley rat cerebellar cell line, and $\mathrm{Ca}^{2+}$ uptake was inhibited by $\alpha$-bungarotoxin, a specific $\alpha_{7} \mathrm{nAChR}$ antagonist. Yeboah et al. (49) suggest that $\alpha_{7}$ nAChRs, which are constitutively expressed in the kidney of SpragueDawley rats, are highly permeable to $\mathrm{Ca}^{2+}$ ions. Duzguner and Erdogan (16) believe that higher plasma $\mathrm{Ca}^{2+}$ concentrations could be responsible for the induction of ROS-generating enzymes xanthine oxidase and myeloperoxidase in the liver and brain of female Wistar rats treated with IMI intravenously. Kimura-Kuroda et al. (48) have suggested that mammalian ACh receptors are affected by IMI exposure because of conformational changes of the receptor induced by ACh. We therefore believe that higher $\mathrm{tChE}$ activity that lowers ACh-assisted IMIbinding may be an adaptive response to oxidative stress induced by elevated $\mathrm{Ca}^{2+}$ uptake. This is supported by Bond et al. (50), who found that AChE release in rat astroglial cells increased in response to $t$-butylhydroperoxide-induced oxidative stress. 

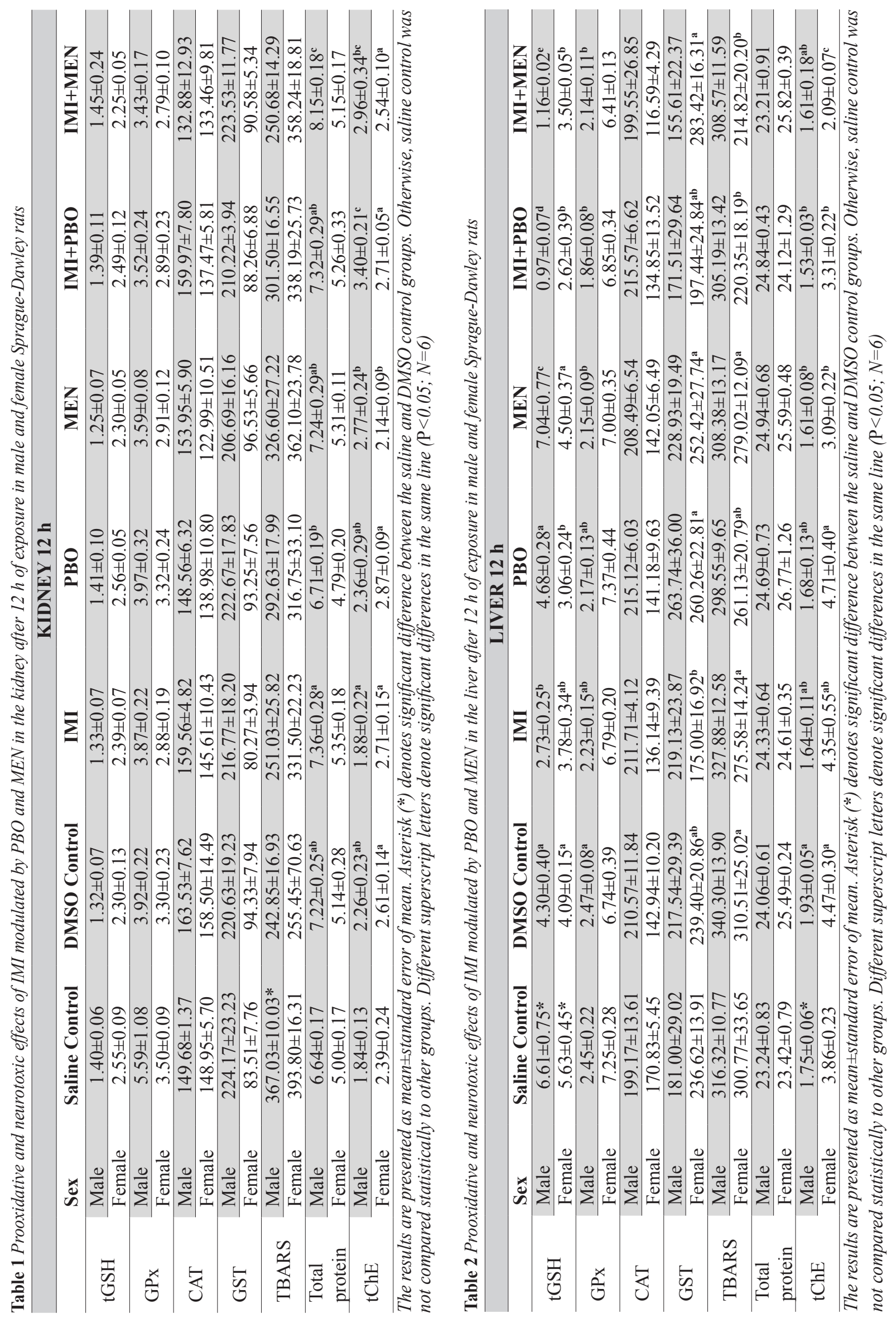
Furthermore, Yang et al. (51) found that $d$-tubocurarine, which is an nAChR antagonist, prevented diisopropylphosphorofluoridate to increase AChrelated ROS and lipid peroxidation in the muscle of male Sprague-Dawley rats.

While the normal range of tChE activity in our study was $1.75-2.30 \mathrm{nmol} \mathrm{L}^{-1}$ per min per mg of protein in male liver and 3.64-3.86 $\mathrm{nmol} \mathrm{L}^{-1}$ per min per $\mathrm{mg}$ of protein in female liver (Tables 2 and 4), literature reports a wide variety of inconclusive findings, and our results were not far from some of these (52-58).

Obregon et al. (59) found that DMSO mixed with different brain region homogenates of male Wistar rats inhibited $\mathrm{ChE}$ activity at all tested concentrations. However, in our study DMSO had no effect on the liver and kidney tChE after i.p. injection, except for a transitory elevation in the liver of male rats at $12 \mathrm{~h}$. Similarly, Carr and Nail (60) reported no DMSO effect on $\mathrm{ChE}$ activities of different brain regions in SpragueDawley pups of either sex, while the serum activity increased significantly. However, this increase did not suffice to protect against chlorpyrifos treatment, just as in our study higher tChE in the DMSO control group did not suffice to protect against IMI $+\mathrm{PBO}$ in male rats. At $12 \mathrm{~h}, \mathrm{IMI}+\mathrm{PBO}$ significantly lowered $\mathrm{tChE}$ activity compared to either saline or DMSO control.

In our study, GPx activity increased and CAT activity decreased in the liver of male rats after $24 \mathrm{~h}$ of exposure (Table 4). CAT and GPx compete for $\mathrm{H}_{2} \mathrm{O}_{2}$ detoxification (61). In a study by Duzguner and Erdogan (16), IMI lowered GPx activity in the liver and increased it in the brain of female Wistar rats, while CAT was not affected. The authors suggested that GPx could be more important than CAT in countering IMI-induced ROS formation.

Table 3 shows that GST activity in our study increased in the kidney of female rats after $24 \mathrm{~h}$ of exposure without a change in TBARS levels. GST catalyses the conjugation of GSH with xenobiotics, including lipid peroxidation products (62), and according to the WHO (31) this reaction is not important in IMI biotransformation. The level of GST subunits 3 and 4 in females are 3-4 times higher than in males, while subunits 1 and 2 are 1.5-2 times higher in the kidney of male rats (63). Gender-specific subunit levels may be related to this increase and further research should look into which GST subunit is responsible for IMI effect in the kidney of female rats.

\section{Effects of PBO on IMI toxicity}

Piperonyl butoxide can be valuable to determine the effects of CYP450-mediated biotransformation on IMI toxicity (10).

We observed no change in oxidative stress parameters in the kidney regardless of sex after $12 \mathrm{~h}$ of exposure (Table 1). However, tGSH content was more pronounced in the liver of male rats treated with IMI+PBO than IMI alone (Table 2). IMI+PBO co-exposure decreased liver GPx activity compared to control, but it did not differ significantly from IMI and PBO alone groups. This lower GPx activity may be associated with lower tGSH, which is a substrate for the enzyme.

IMI+PBO decreased total protein content in the liver of male rats after $24 \mathrm{~h}$ of exposure (Table 4 ). GPx activity dropped, while CAT remained within the control range. This suggests that GPx is more involved in IMI-induced oxidative stress than CAT. Lower CAT activity in the liver of female rats also supports this hypothesis because no change was observed in tGSH, TBARS, and total protein content (Table 4). Since PBO inhibits CYP450 enzymes, the accumulation of the parent IMI compound may provide more substrate for other biotransformation pathways such as AOX. This elevation in AOX activity could explain the oxidative effects in the liver of male rats. A similar explanation was suggested by Valentovic et al. (64), who said that increased liver toxicity of 3,5-dichloroaniline given with PBO could be related to the metabolites of the parent compound produced by metabolic processes other than CYP450.

Unlike the liver, the kidney of male rats was partly protected against IMI toxicity by PBO pre-treatment; it had no effect on increased tGSH and decreased total protein content in the kidney of male rats after $24 \mathrm{~h}$ of exposure (Table 3). However, TBARS levels, which increased in the IMI and PBO alone groups, did not increase significantly in respect to control. Baliga et al. (65) found that PBO provided protection against $\mathrm{H}_{2} \mathrm{O}_{2}$-induced cytotoxicity in proximal tubular cell line LLC-PK1 and they suggested that CYP450 may have served as a source of catalytic iron in ROS production pathways.

Co-exposure to IMI+PBO lowered liver tGSH and TBARS in females after $12 \mathrm{~h}$ of exposure (Table 2); while there was no change in the IMI alone group. These changes seem to be related to PBO pretreatment. Muguruma et al. (66) reported that PBO increased microsomal ROS production in the liver. 

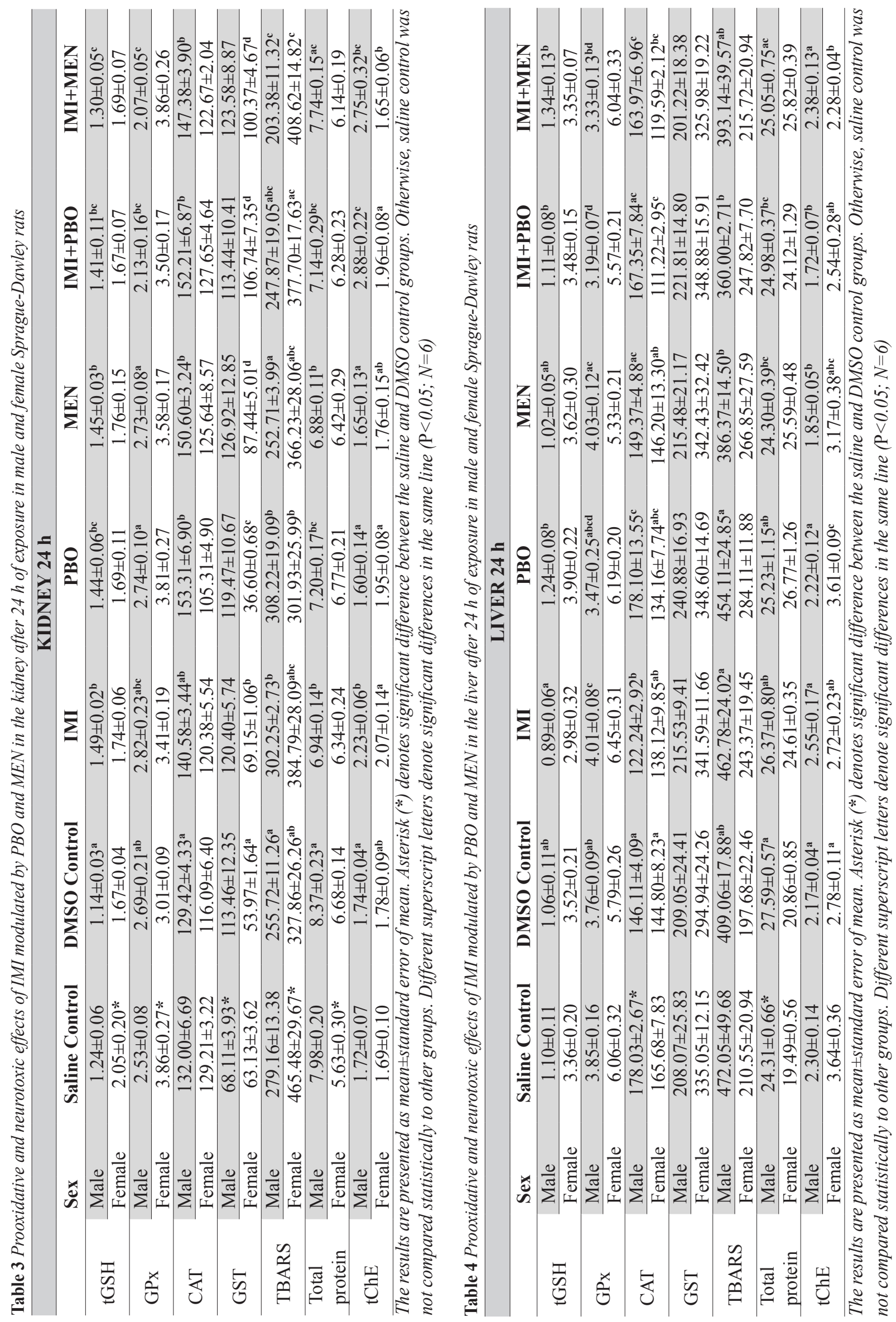
This suggests that lower TBARS levels in the present study could be attributed to lower tGSH levels that act against ROS production.

Furthermore, co-exposure to IMI+PBO displayed tissue-specific effect of IMI on tChE activity. In the kidney of male rats, it was higher than in control, IMI, and PBO groups after 12 and $24 \mathrm{~h}$ of exposure (Tables 1 and 3 ). We believe that increased tChE activity may be an adaptive response against oxidative stress, as we discussed earlier. In the liver of male rats, however, tChE activity dropped significantly compared to control, IMI, and PBO groups after $24 \mathrm{~h}$ of exposure (Table 4). IMI+PBO also lowered tChE activity after $12 \mathrm{~h}$ of exposure compared to control (Table 2). Liver tChE activity also dropped in females compared to control, IMI, and PBO groups after $12 \mathrm{~h}$ (Table 2), while it remained within the control range after $24 \mathrm{~h}$ of exposure. $\mathrm{PBO}$ alone increased tChE activity (Table 4). While some authors $(14,15)$ reported that IMI lowered ChE, tissue-specific effects of IMI on tChE activity require further investigation.

\section{Effects of MEN on IMI toxicity}

Interestingly, MEN as a modulator of IMI metabolism has revealed similar tissue-specific effect of IMI on tChE activity as observed in PBO coexposure. MEN lowered tChE activity in the kidney female rats (Table 1). Similarly, Torda and Wolff (67) reported that MEN decreased ChE activity in human serum. However, IMI+MEN co-exposure resulted in no significant change, probably due to the antagonistic effect of IMI against MEN. In contrast, IMI+MEN co-exposure lowered liver $\mathrm{tChE}$ activity in female rats compared to control, IMI, and MEN alone groups in both exposure durations (Table 2 and 4). Therefore, we are convinced that IMI, whose metabolism was inhibited by $\mathrm{PBO}$ or MEN, inhibits liver tChE activity.

Menadione co-exposure proved to be useful against oxidative stress in the kidney of male rats after $24 \mathrm{~h}$ of exposure (Table 3 ). It countered the TBARSincreasing and protein-lowering effects of IMI. It also lowered IMI-induced tGSH, while GPx decreased and CAT increased. Kitamura et al. (68) reported that AOX catalysed fenthion metabolism to fenthion sulphoxide, and that this transformation was inhibited by MEN and $\beta$-oestradiol in the liver of male Sprague-Dawley rats. Similarly, Honda et al. (8) reported that MEN decreased AOX activity in mouse fibroblast M10 cells. These findings suggest that MEN co-exposure may have inhibited AOX-mediated biotransformation of IMI in our study and therefore the oxidative effects of its metabolites. Elevated tChE activity in this group may also have contributed to the protection against oxidative stress as discussed above.

In female rats, MEN co-exposure also revealed the oxidative effects of IMI in both tissues. Liver TBARS and tGSH levels were significantly lower than in the control, IMI, and MEN alone groups after $12 \mathrm{~h}$ of exposure (Table 2). Higher kidney GST activity and TBARS levels were observed in IMI+MEN group after $24 \mathrm{~h}$ of exposure (Table 3 ). In the liver of male rats, tGSH and GPx activity dropped, but total protein content and lipid peroxidation levels did not change after $12 \mathrm{~h}$ of exposure (Table 2). In the liver of male Wistar rats, Sidorova and Grishanova (69) found that MEN increased total CYP450 content, GST, and a variety of CYP450 enzyme activities, including CYP1A2, the enzyme that catalyses nitroimine reduction of IMI. This suggests that, CYP450mediated metabolism of IMI could be accelerated by MEN co-exposure and contribute to IMI-related oxidative effects, especially in female rats, despite possible inhibition of AOX activity. Because of the opposite effects of MEN co-exposure (AOX inhibition and CYP450 induction), further in vivo studies with the same doses of IMI and MEN should investigate the mechanisms that affect CYP450 and AOX activities.

\section{CONCLUSIONS}

This is the first study that shows tissue-, exposure duration-, and sex-differences in the prooxidative and neurotoxic potential of IMI in rats. IMI's oxidative and neurotoxic effects after $24 \mathrm{~h}$ of exposure were probably related to its metabolism. The most pronounced prooxidative effect was observed in the kidney of male rats, and it may be related to hormonal effects on the enzymes that participate in IMI metabolism. However, further investigation is needed to evaluate the effects of sex hormones on CYP450s and AOX activity in the presence of IMI. IMI has also shown a tissue-specific effect on $\mathrm{tChE}$ activity, which was clarified by metabolic modulators PBO and MEN. Interestingly, $\mathrm{PBO}$ and MEN co-exposure exacerbated the prooxidative effects of IMI in the liver of male rats, while no change or a decrease was found in $\mathrm{tChE}$ activity. This points to a synergy between IMI and PBO in the liver, which could be more toxic to mammals in terms of oxidative stress and neurotoxicity. In contrast, $\mathrm{PBO}$ and MEN co-exposure alleviated the 
prooxidative effects of IMI in the kidney, as evidenced by a significant rise in tChE activity in these groups. This calls for further investigation of the protective role of cholinesterase against IMI-induced oxidative stress. MEN co-exposure was also useful in revealing the oxidative effects of IMI in female rats in both tissues because IMI alone and MEN alone had no effects in females.

\section{Acknowledgements}

We wish to thank the Adiyaman University Scientific Research Commission for supporting our study through project grants no. FEFBAP2011/007 and FEFYL2011/0011. We also wish to thank Dado Cakalo for having edited the manuscript to read better. We have no conflict of interest to declare.

\section{REFERENCES}

1. Tomizawa M, Casida JE. Neonicotinoid insecticides: highlights of a symposium on strategic molecular designs. J Agric Food Chem 2011;59:2883-6. doi: 10.1021/jf103856c

2. Kovganko NV, Kashkan ZhN. Advances in the synthesis of neonicotinoids. Russ J Org Chem 2004;40:1709-26. doi: 10.1007/s11178-005-0089-y

3. Tomizawa M, Casida JE. Neonicotinoid insecticide toxicology: mechanisms of selective action. Annu Rev Pharmacol Toxicol 2005;45:247-68. doi: 10.1146/annurev. pharmtox.45.120403.095930

4. EPA. Imidacloprid Summary Document Registration Review: Initial Docket December 2008. EPA-HQ-OPP-2008-0844 [displayed 7 July 2014]. Available at http://agri-pulse.com/ uploaded/EPA_2008_Imidacloprid.pdf

5. Tomizawa M, Casida JE. Selective toxicity of neonicotinoids attributable to specificity of insect and mammalian nicotinic receptors. Annu Rev Entomol 2003;48:339-64. doi: 10.1146/ annurev.ento.48.091801.112731

6. Chao SL, Casida JE. Interaction of imidacloprid metabolites and analogs with the nicotinic acetylcholine receptor of mouse brain in relation to toxicity. Pestic Biochem Physiol 1997;58:77-88. doi: 10.1006/pest.1997.2284

7. Tomizawa M, Casida JE. Imidacloprid, thiacloprid, and their imine derivatives up-regulate the $\alpha 4 \beta 2$ nicotinic acetylcholine receptor in M10 cells. Toxicol Appl Pharmacol 2000;169:11420. doi: 10.1006/taap.2000.9057

8. Honda H, Tomizawa M, Casida JE. Neonicotinoid metabolic activation and inactivation established with coupled nicotinic receptor-CYP3A4 and -aldehyde oxidase systems. Toxicol Lett 2006;161:108-14. doi: 10.1016/j.toxlet.2005.08.004

9. Costa C, Silvari V, Melchini A, Catania S, Heffron JJ, Trovato A, De Pasquale R. Genotoxicity of imidacloprid in relation to metabolic activation and composition of the commercial product. Mutat Res 2009;672:40-4. doi: 10.1016/j. mrgentox.2008.09.018

10. Schulz-Jander DA, Casida JE. Imidacloprid insecticide metabolism: human cytochrome P450 isozymes differ in selectivity for imidazolidine oxidation versus nitroimine reduction. Toxicol Lett 2002;132:65-70. PMID: 12084621

11. Dick RA, Kanne DB, Casida JE. Identification of aldehyde oxidase as the neonicotinoid nitroreductase. Chem Res Toxicol 2005;18:317-23. PMID: 15720138

12. Capowiez Y, Rault M, Mazzia C, Belzunces L. Earthworm behaviour as a biomarker - a case study using imidacloprid. Pedobiologia 2003;47:542-7. doi: 10.1078/0031-4056-00226

13. Abou-Donia MB, Goldstein LB, Bullman S, Tu T, Khan WA, Dechkovskaia AM, Abdel-Rahman AA. Imidacloprid induces neurobehavioral deficits and increases expression of glial fibrillary acidic protein in the motor cortex and hippocampus in offspring rats following in utero exposure. J Toxicol Environ Health Part A 2008;71:119-30. doi: 10.1080/15287390701613140

14. Bhardwaj S, Srivastava MK, Kapoor U, Srivastava LP. A 90 days oral toxicity of imidacloprid in female rats: Morphological, biochemical and histopathological evaluations. Food Chem Toxicol 2010;48:1185-90. doi: 10.1016/j.fct.2010.02.009

15. Dondero F, Negri A, Boatti L, Marsano F, Mignone F, Viarengo A. Transcriptomic and proteomic effects of a neonicotinoid insecticide mixture in the marine mussel (Mytilus galloprovincialis, Lam.). Sci Total Environ 2010;408:3775-86. doi: 10.1016/j.scitotenv.2010.03.040

16. Duzguner V, Erdogan S. Acute oxidant and inflammatory effects of imidacloprid on the mammalian central nervous system and liver in rats. Pestic Biochem Physiol 2010;97:138. doi: 10.1016/j.pestbp.2009.11.008

17. El-Gendy KS, Aly NM, Mahmoud FH, Kenawy A, El-Sebae $\mathrm{AH}$. The role of vitamin $\mathrm{C}$ as antioxidant in protection of oxidative stress induced by imidacloprid. Food Chem Toxicol 2010;48:215-21. doi: 10.1016/j.fct.2009.10.003

18. Kapoor U, Srivastava MK, Bhardwaj S, Srivastava LP. Effect of imidacloprid on antioxidant enzymes lipid peroxidation in female rats to derive its No Observed Effect Level (NOEL). J Toxicol Sci 2010;35:577-81. PMID: 20686345

19. Kapoor U, Srivastava MK, Srivastava LP. Toxicological impact of technical imidacloprid on ovarian morphology, hormones and antioxidant enzymes in female rats. Food Chem Toxicol 2011;49:3086-9. doi: 10.1016/j.fct.2011.09.009

20. Nebbia C. Biotransformation enzymes as determinants of xenobiotic toxicity in domestic animals. Vet J 2001;161:23852. doi: $10.1053 /$ tvj1.2000.0561

21. Ghanayem BI, Hoffler U. Investigation of xenobiotics metabolism, genotoxicity, and carcinogenicity using cyp2e1-/- mice. Curr Drug Metab 2007;8:728-49. PMID: 17979661

22. Sivori JL, Casabé N, Zerba EN, Wood EJ. Induction of glutathione $S$-transferase activity in Triatoma infestans. Mem Inst Oswaldo Cruz 1997;92:797-802. PMID: 9566212

23. Bingham G, Strode C, Tran L, Khoa PT, Jamet HP. Can piperonyl butoxide enhance the efficacy of pyrethroids against pyrethroid-resistant Aedes aegypti? Trop Med Int Health 2011;16:492-500. doi: 10.1111/j.1365-3156.2010. 02717.x

24. Urek SY, Baydan E, Yurdakök B, Akaydin Y, Kozlu T, Tunca A. Subacute toxicity of piperonyl butoxide and resmethrin in mice. Afr J Pharm Pharmacol 2012;6:2083-7. doi: 10.5897/ AJPP12.851 
25. Abe K, Saito H. Menadione toxicity in cultured rat cortical astrocytes. Jpn J Pharmacol 1996;72:299-306. doi: 10.1254/ jjp.72.299

26. Chung JH, Seo DC, Chung SH, Lee JY, Seung SA. Metabolism and cytotoxicity of menadione and its metabolite in rat platelets. Toxicol Appl Pharmacol 1997;142:378-85. PMID: 9070361

27. Cui D, Rankin G, Harvison PJ. Transamination in the metabolism of the nephrotoxicant $n$-(3,5-dichlorophenyl) succinimide in rats. Drug Metab Dispos 2005;33:1765-70. doi: $10.1124 / \mathrm{dmd} .105 .006593$

28. Kerver ED, Vogels IMC, Bosch KS, Vreeling-Sindelarova H, Van Den Munckhof RJM, Frederiks WM. In situ detection of spontaneous superoxide anion and singlet oxygen production by mitochondria in rat liver and small intestine. Histochem J 1997;29:229-37. PMID: 9472385

29. Al-Omar MA, Al-Arifi MN. Comparative effects of scopoletin and menadione on aldehyde oxidase activity of guinea pig liver. J Biol Sci 2005;5:525-31. doi: 10.3923/ jbs.2005.525.531

30. Sanmartín-Suárez C, Soto-Otero R, Sánchez-Sellero I, Méndez-Álvarez E. Antioxidant properties of dimethyl sulfoxide and its viability as a solvent in the evaluation of neuroprotective antioxidants. J Pharmacol Toxicol Methods 2011;63:209-15. doi: 10.1016/j.vascn.2010.10.004

31. IPCS/INCHEM. Pesticide residues in food. Toxicological evaluations: imidacloprid. 2001. [displayed 7 July 2014] Available at http://www.inchem.org/documents/jmpr/ jmpmono/2001pr07.htm

32. Anderson ME. Determination of glutathione and glutathione disulfide in biological samples. Methods Enzymol 1985;113:548-55. PMID: 4088074

33. Beutler E. Red Cell Metabolism: A Manual of Biochemical Methods. $2^{\text {nd }}$ Ed. New York (NY): Grune and Starton; 1984.

34. Habig WH, Pabst MJ, Jakoby WB. Glutathione $S$-transferases. The first enzymatic step in mercapturic acid formation. J Biol Chem 1974;249:7130-9. PMID:4436300

35. Wills ED. Mechanism of lipid peroxide formation in animal tissues. Biochem J 1966; 99:667-76. PMID: 5964963

36. Lowry OH, Rosebrough NJ, Farr AL, Randall RJ. Protein measurement with Folin-phenol reagent. J Biol Chem 1951;193:265-75. PMID: 14907713

37. Ellman GL, Courtney KD, Andres V, Featherstone RM. A new and rapid colorimetric determination of acetycholinesterase activity. Biochem Pharmacol 1961;7:8895. doi: 10.1016/0006-2952(61)90145-9

38. Rankin GO. Kidney. In: Wexler P, editor. Encylopedia of toxicology. $2^{\text {nd }}$ ed. New York (NY): Academic Press; 2005. p. 666-89.

39. Broznić D, Marinić J, Tota M, Čanadi Jurešić G, Milin C. Kinetic evaluation of imidacloprid degradation in mice organs treated with olive oil polyphenols extract. Croat Chem Acta 2008;81:203-9.

40. EMEA. European Medicines Agency, Scientific Discussion, CVMP/0297/03 2009 [displayed 7 July 2014]. Available at http://www.ema.europa.eu/docs/en_GB/document_library/ EPAR_-_Scientific_Discussion/veterinary/000076/ WC500060915.pdf

41. Yildiz D, Ercal N, Armstrong DW. Nicotine enantiomers and oxidative stress. Toxicology 1998;130:155-65. doi: 10.1016/ S0300-483X(98)00105-X
42. Kyerematen GA, Owens GF, Chattopadhyay B, de Bethizy JD, Vesell ES. Sexual dimorphism of nicotine metabolism and distribution in the rat, studies in vivo and in vitro. Drug Metab Dispos 1988;16:823-8. PMID: 2907460

43. Kammerer B, Scheible H, Albrecht W, Gleiter CH, Laufer S. Pharmacokinetics of ML3403 (\{4-[5-(4-fluorophenyl)-2methylsulfanyl-3H-imidazol-4-yl]-pyridin-2-yl $\}-(1-$ phenylethyl)-amine), a 4-Pyridinylimidazole-type p38 mitogen-activated protein kinase inhibitor. Drug Metab Dispos 2007;35:875-83. doi: 10.1124/dmd.106.013409

44. Sundseth SS, Waxman DJ. Sex-dependent expression and clofibrate inducibility of cytochrome P450 4A fatty acid a-hydroxylases. J Biol Chem 1992;267:3915-21. PMID: 1740439

45. Kundu TK, Velayutham M, Zweier JL. Aldehyde oxidase functions as a superoxide generating NADH oxidase: an important redox regulated pathway of cellular oxygen radical formation. Biochemistry 2012;51:2930-9. doi: 10.1021/ bi3000879

46. Huh K, Shin US, Choi JW, Lee SI. Effect of sex hormones on lipid peroxidation in rat liver. Arch Pharm Res 1994;17:109-14. PMID: 10319141

47. Ventura SM, Dachtler SL. Effects of sex hormones on hepatic aldehyde oxidase activity in C57BL/6J mice. Horm Res 1981;14:250-9. PMID: 7308982

48. Kimura-Kuroda J, Komuta Y, Kuroda Y, Hayashi M, Kawano $\mathrm{H}$. Nicotine-like effects of the neonicotinoid insecticides acetamiprid and imidacloprid on cerebellar neurons from neonatal rats. PLoS One 2012;7:e32432. doi: 10.1371/ journal.pone.0032432

49. Yeboah MM, Xue X, Javdan M, Susin M, Metz CN. Nicotinic acetylcholine receptor expression and regulation in the rat kidney after ischemia-reperfusion injury. Am J Physiol Renal Physiol 2008;295:654-61. doi: 10.1152/ajprenal.90255.2008

50. Bond CE, Patel P, Crouch L, Tetlow N, Day T, Abu-Hayyeh $\mathrm{S}$, Williamson C, Greenfield SA. Astroglia up-regulate transcription and secretion of 'readthrough' acetylcholinesterase following oxidative stress. Eur J Neurosci 2006;24:381-6. PMID: 16903848

51. Yang ZP, Morrow J, Wu A, Roberts LJ, Dettbarn WD. Diisopropylphosphofluoridate-induced muscle hyperactivity associated with enhanced lipid peroxidation in vivo. Biochem Pharmacol 1996;52:357-61. PMID: 8694861

52. García-Ayllón MS, Silveyra MX, Candela A, Compañ A, Clària J, Jover R, Pérez-Mateo M, Felipo V, Martínez S, Galcerán J, Sáez-Valero J. Changes in liver and plasma acetylcholinesterase in rats with cirrhosis induced by bile duct ligation. Hepatology 2006;43:444-53. PMID: 16496349

53. Hazarika A, Sarkar SN. Subacute toxicity of anilofos, a new organophosphorus herbicide, in male rats: Effect on some physical attributes and acetylcholinesterase activity. Indian J Exp Biol 2001;39:1107-12. PMID: 11906102

54. Borges HE, Martins ACP, Mathias PCF, Esteves RZ. Atividade colinesterásica em tireóide de ratos: resposta a uma sobrecarga de iodo [Cholinesterase activity in rat thyroid in response to iodine overload, in Portuguese]. Arq Bras Endocrinol Metab 2000;44:347-51.

55. Berninsone P, Katz E, Napp M, Azcurra J. Acetylcholinesterase and nonspecific cholinesterase activities in rat liver: subcellular localization, molecular forms, and some extraction properties. Biochem Cell Biol 1989;67:817-22. doi: $10.1139 / 089-121$ 
56. Shih T-M. Comparison of several oximes on reactivation of soman-inhibited blood, brain and tissue cholinesterase activity in rats. Arch Toxicol 1993;67:637-46. doi: 10.1007/ BF01974071

57. Kaur B, Khera A, Sandhir R. Attenuation of cellular antioxidant defense mechanisms in kidney of rats intoxicated with carbofuran. J Biochem Mol Toxicol 2012;26:393-8. doi: $10.1002 / \mathrm{jbt} .21433$

58. Iwata $\mathrm{H}$, Inoue A, Tomoi M. Enhancement of brain thiamine diphosphatase activity of rats by injection of cholinerg1c drugs. J Neurochem 1971;18:1371-7. doi: 10.1111/j.1471-4159.1971.tb00001.x

59. Obregon ADC, Schetinger MRC, Correa MM, Morsch VM, da Silva JEP, Martins MAP, Bonacorso HG, Zanatta N. Effects per se of organic solvents in the cerebral acetylcholinesterase of rats. Neurochem Res 2005;30:37984. doi: 10.1007/s11064-005-2612-5

60. Carr RL, Nail CA. Effect of different administration paradigms on cholinesterase inhibition following repeated chlorpyrifos exposure in late preweanling rats. Toxicol Sci 2008;106:186-92. doi: 10.1093/toxsci/kfn164

61. Debnath D, Mandal TK. Study of quinalphos (an environmental oestrogenic insecticide) formulation (Ekalux 25 E.C.)-induced damage of the testicular tissues and antioxidant defence systems in Sprague-Dawley albino rats. J Appl Toxicol 2000;20:197-204. PMID: 10797472

62. Cnubben NHP, Rietjens IMCM, Wortelboer H, Zanden JV, van Bladeren PJ. The interplay of glutathione-related processes in antioxidant defense. Environ Toxicol Pharmacol 2001;10:141-52. PMID: 21782570

63. Butera L, Fenfeld DA, Bhargava M. Sex differences in the subunits of glutathione-S-transferase isoenzyme from rat and human kidney. Enzyme 1990;43:175-82. PMID: 2101797

64. Valentovic MA, Lo HH, Brown PI, Rankin GO. 3,5-Dichloroaniline toxicity in Fischer 344 rats pretreated with inhibitors and inducers of cytochrome P450. Toxicol Lett 1995;78:207-14. PMID: 7624891

65. Baliga R, Zhang Z, Shah SV. Role of cytochrome P-450 in hydrogen peroxide-induced cytotoxicity to LLC-PK1 cells. Kidney Int 1996;50:1118-24. doi: 10.1038/ki.1996.418

66. Muguruma M, Unami A, Kanki M, Kuroiwa Y, Nishimura J, Dewa Y, Umemura T, Oishi Y, Mitsumori K. Possible involvement of oxidative stress in piperonyl butoxide induced hepatocarcinogenesis in rats. Toxicology 2007;236:61-75. PMID: 17498859

67. Torda C, Wolff HG. Effect of vitamin K (menadione) on choline esterase activity, acetylcholine synthesis, and striated muscle. Exp Biol Med 1944;57:236-9. doi: 10.3181/0037972757-14766

68. Kitamura S, Suzuki T, Ohta S, Fujimoto N. Antiandrojenic activity and metabolism of the organophosphorus pesticide fenthion and related compounds. Environ Health Perspect 2003;111:503-8. doi: 10.1289/ehp.5917

69. Sidorova YA, Grishanova AY. Dose- and time-dependent effects of menadione on enzymes of xenobiotics in rat liver. Bull Exp Biol Med 2004;137:231-4. PMID: 15232626 


\title{
Sažetak
}

Djelovanje imidakloprida pod utjecajem piperonil butoksida i menadiona ovisno je o spolu, tkivu i trajanju izloženosti. I. dio - oksidativno i neurotoksično djelovanje

Rezultati ranijih istraživanja pokazali su oksidativni i neurotoksični potencijal imidakloprida, neonikotinoidnog insekticida, u različitih životinjskih vrsta. Primarni je cilj ovog istraživanja bio utvrditi kako modulatori metabolizma piperonil butoksid i menadion utječu na nepovoljne učinke imidakloprida na jetra i bubrege muških i ženskih štakora soja Sprague-Dawley. Životinje su $12 \mathrm{~h}$ odnosno $24 \mathrm{~h}$ bile izložene samo imidaklopridu ( $\left.170 \mathrm{mg} \mathrm{kg}^{-1}\right)$ ili njegovoj kombinaciji s piperonil butoksidom (100 $\left.\mathrm{mg} \mathrm{kg}^{-1}\right)$ odnosno menadionom $\left(25 \mathrm{mg} \mathrm{kg}^{-1}\right)$. U homogenatima jetara i bubrega spektrofotometrijski su utvrđene razine glutation peroksidaze, glutation S-transferaze, katalaze, specifične aktivnosti ukupne kolinesteraze, ukupni glutation, ukupni proteini te razine lipidne peroksidacije. Imidakloprid se pokazao prooksidativnim i neurotoksičnim uglavnom u bubrezima muških štakora nakon 24-satne izloženosti. Naši rezultati upućuju na to da su razlike u prooksidativnom i neurotoksičnom djelovanju imidakloprida povezane sa spolnim razlikama. Predtretmanom piperonil butoksidom odnosno menadionom (90 min prije davanja imidakloprida) otkriveno je da imidakloprid djeluje na ukupnu aktivnost kolinesteraze specifično za pojedina tkiva. Povišena aktivnost kolinesteraza u bubrezima mogla bi odražavati prilagodbu na oksidativni stres uzrokovan imidaklopridom. Piperonil butoksid odnosno menadion u jetrima muških štakora samo su pogoršali toksičnost imidakloprida. U ženki je djelovanje imidakloprida s menadionom bilo prooksidativno; takvo se djelovanje nije vidjelo nakon primjene samo imidakloprida odnosno samo menadiona. Vjerujemo da je promjenjivo djelovanje imidakloprida s obzirom na spol, tkivo i trajanje izloženosti važno za daljnja istraživanja njegove toksičnosti.

KLJUČNE RIJEČI: glutation peroksidaza; glutation S-transferaza; katalaza; kolinesteraza; neonikotinoidi; oksidativni stres

\section{CORRESPONDING AUTHOR:}

\author{
Yusuf Sevgiler \\ Adiyaman University, Faculty of Science and Letters, \\ Department of Biology \\ 02040 Adiyaman, Turkey \\ E-mail:ysevgiler@adiyaman.edu.tr,ysevgiler@gmail.com
}

